\title{
MATURATION AND GROWTH CURVES OF MACROBRACHIUM CARCINUS (LINNAEUS) (CRUSTACEA, DECAPODA, PALAEMONIDAE) FROM RIBEIRA DE IGUAPE RIVER, SOUTHERN BRAZIL
}

\author{
Wagner C. Valenti ${ }^{1}$ \\ Jeanette de T.C. de Mello ${ }^{2}$ \\ Vera L. Lobão ${ }^{3}$
}

\begin{abstract}
In this paper, female Macrobrachitum carcinus (Linnaeus, 1758) maturation curve, weight/length relationship, length and weight growth curves were studied. Prawns were captured, by traps, in Ribeira de Iguape river $\left(24^{\circ} \mathrm{S}\right.$ and $\left.47^{\circ} \mathrm{W}\right)$, southern Brazil. There were used 207 females. It was observed that M. carcinus presents several spawnings during its life cycle and reproductive period goes on, at least till six years old. Weight/length relationship can be represented for the equation $\mathrm{W}=8.73 \mathrm{E}-3 \mathrm{~L}^{3.28}$. Expressions obtained for length and weight growth curves are $\mathrm{L}=21.0\left(1-\mathrm{e}^{-0.493 t}\right)$ and $\mathrm{W}_{1}=190\left(1-\mathrm{e}^{-0.4931}\right)^{3.28}$, respectively. Asymptotic maximum length and asymptotic maximum weight are nearly attained at six and eight years old, respectively.

KEY WORDS. Crustacea, Macrobrachium, maturation, growth, prawn
\end{abstract}

Macrobrachium carcinus (Linnaeus, 1758) is a large decapod crustacean found naturally in Antilles and Atlantic America, ranging from Florida to southern Brazil, inhabiting the bottom of fresh and brackish waters (HoLTHUIS 1952, 1980; BOND \& BUCKUP 1989). This is a species of commercial interest exploited by fishery in several countries and has been studied for aquaculture purposes (LiNG \& Costelo 1976; Holthuis 1980; Rabanal 1982; Chauvin 1992).

Reproduction and growth studies are central topics of fishery biology and autoecology (WEATHERLEY 1972; PAULY 1980), being also fundamental to assess the potential for culture or natural stock exploitation of a species. Both for practical applications and theoretical reasons, growth must be expressed by means of curves or models that give a generalized description of its pattern (BEVERTON \& HOLT 1957; Bagenal 1978; Pauly 1980).

1) Departamento de Biologia Aplicada, Faculdade de Ciências Agrárias e Veterinária e Núcleo de Estudos de Biologia. Ecologia e Cultivo de Crustácesos, Centro de Aquicultura, Universidade Estadual Paulista, Rodovia Carlos Tonanni Km 5, 14.870-000 Jaboticabal, São Paulo, Brasil. Bolsista do CNPq.

2) Departamento de Biologia, Iinstituto de Bioviências, Universidade de São Paulo, Caixa Postal 11461 , 05422-970 São Paulo, São Paulo, Brasil.

3) Seção de Aquicultura. Instituto de Pessea, Av. Francisco Matarazzo 45.5, 05131-900 São Paulo, São Paulo, Brasil. Bolsista do CNPq. 
In this paper, female $M$. corcinus maturation curve, weight/length relationship, length and weight growth curves were studied.

\section{MATERIAL AND METHODS}

From August 1978 to May 1979 and in January/February 1983207 females of $M$. carcinus were captured in Ribeira de Iguape river $\left(24^{\circ} \mathrm{S}\right.$ and $\left.47^{\circ} \mathrm{W}\right)$, São Paulo, southern Brazil. They were catch by traps $(0.5 \mathrm{~cm}$ mesh) using fish flesh bait. For each prawn, total length (measured from rostrum tip to telson tip), total weight and the gonad weight were determined. Gonads were weighed to the nearest 0,1 milligram.

Weight (W) / length (L) relationship was fitted by linear regression, applied after the logarithmic transformation of the data grouped in classes of $0.5 \mathrm{~cm}$. It was represented by:

$$
W=a L^{b}
$$

where $a$ and $b$ are constants.

Maturation curve was determined by plotting mean gonad weight against total weight (grouped in classes of $10 \mathrm{~g}$ ), obtaining in this way, the mean weights in each spawning (SANTOS 1972). Corresponding mean lengths were achieved by means of the weight/length relationship and with these data the length growth curve was estimated, according SANTOS (1972).

In a previous paper (VALENTI et al. 1986), we demonstrated that this population presented a periodic annual reproductive cycle, that is, the spawnings were separated by an almost constant period corresponding to one year.

Therefore, we could use the Ford-Walford method (WALFORD 1946), plotting the mean length at one spawning $\left(L_{l}+\Delta t\right)$ against the mean length at the preceding spawning $\left(L_{l}\right)$. Linear relationship obtained suggests that, in this species, growth can be represented by the von Bertalantfy's model (BERTALANFFY 1938), which may be represented in the following form:

$$
L_{t}=L_{\infty}\left\{1-e^{-K\left(t-t_{o}\right)}\right\}
$$

Where: $\mathrm{L}_{\mathrm{t}}=$ the mean length at age $\mathrm{t}$; $\mathrm{L}_{\infty}=$ the asymptotic maximum length reached by the animal; $\mathrm{K}=$ growth coefficient; $\mathrm{t}_{\mathrm{o}}=$ parameter related to the animal's length at birth $\left(\mathrm{L}_{0}\right)$.

Rearranging this expression we have:

$$
t_{0}=t+(1 / K) \ln \left\{\left(L_{\infty}-L_{t}\right) / L_{\infty}\right\}
$$

At birth $t=0\left(L_{t}=L_{O}\right)$ and so:

$$
t_{0}=(1 / K) \ln \left\{\left(L_{\infty}-L_{0}\right) / L_{\infty}\right\}
$$


Thus, in species like $M$. carcinus, whose length at birth $\left(\mathrm{L}_{0}\right)$ is negligible in relation to the maximum length attained, $t_{0}=0$ and therefore the expression above can be reduced to:

$$
L_{t}=L_{\omega}\left(1-e^{-K t}\right)
$$

(SANTOS 1978)

With the mean spawning lengths and the Lo value (estimated by means of Ford-Walford method) we determined the parameter $\mathbf{K}$ and the age $\left(\mathbf{t}_{1}\right)$ at the first spawning showed in maturation curve as follows:

Being t' the period between each spawning and the first, the age at each spawning $(\mathrm{t})$ will $\mathrm{b}$ :

$$
t=t_{1}+t^{\prime} \text { for } t^{\prime}=\{0,1,2,3,4\}
$$

Substituting (3) in (2) we have:

$$
\begin{array}{r}
L_{t}=L_{\infty}\left\{1-e^{-K\left(t_{1}+t^{\prime}\right)}\right\} \\
\ln \left\{\left(L_{\infty}-L_{t}\right) L_{\infty}\right\}=-K t_{1}-K t^{\prime}
\end{array}
$$

Using the $\mathrm{L}_{t}$ values and their corresponding t' values we estimated the coefficients of the expression (4) by linear regression, and obtained $\mathrm{K}$ and $\mathrm{t}_{\mathrm{I}}$ values.

Weight growth curve was fitted by deductive method according Santos (1978). From (1) and (2) we have:

$$
\begin{aligned}
& W_{t}=a\left\{L_{\infty}\left(1-e^{-K t}\right)\right\}^{b} \\
& W_{t}=a L_{\infty}{ }^{b}\left(1-e^{-K t}\right)^{b} \\
& W_{t}=W_{\infty}\left(1-e^{-K t}\right)^{b}
\end{aligned}
$$

\section{RESULTS}

Weight (W)/length (L) relationship and linear relationship obtained by plotting $\ln \mathbf{W}$ against $\ln \mathbf{L}$ are showed in figures 1 and 2, respectively.

It can be noted in figure 3 that the mean gonad weight increases as the prawn grows until the spawning starts, decreasing after that due to egg laying. This process is repeated successively until the end of the animal reproductive life.

M. carcinus presents several spawnings during its life cycle. According to figure 3 , they occur when the animal presents a mean weight of $55 ; 95 ; 125 ; 145$ e $165 \mathrm{~g}$. The weight intervals decrease between the spawnings point out the asymptotic growth. From the weight/length relationship these values were converted to female mean length at each spawning (Table I).

Linear relationship resulting of Ford-Walford method is presented in figure 4. 


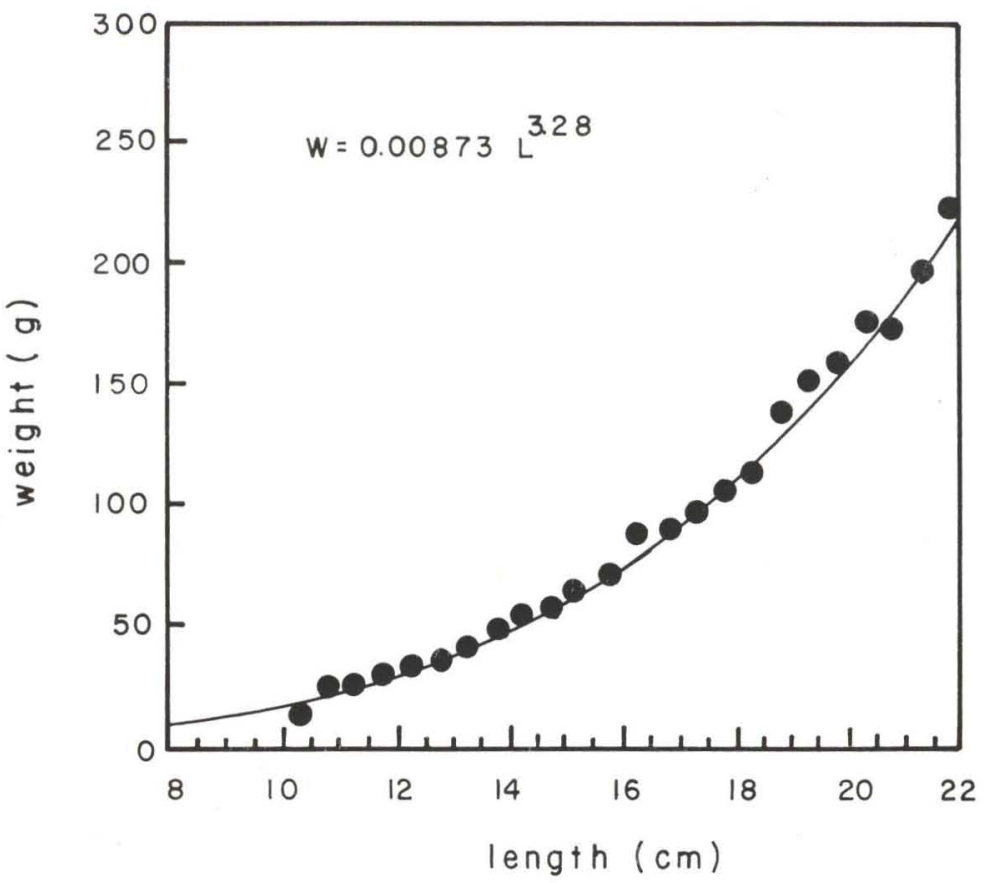

Fig. 1. Length/weight relationship fitted for $M$. carcinus females.

Table I. Mean spawning lengths $\left(L_{\ell}\right)$, period between each spawning and the first ( $\left(t^{\prime}\right)$ and corresponding $\ln \left[\left(\mathrm{L}_{\infty}-\mathrm{L}_{\mathrm{t}}\right) / \mathrm{L}_{\infty} \mid\right.$ values.

\begin{tabular}{ccc}
\hline$L_{t}(\mathrm{~cm})$ & $\mathrm{t}^{\prime}$ (years) & $\ln \left[\left(\mathrm{L}_{\infty}-L_{t}\right) / \mathrm{L}_{\infty}\right]$ \\
\hline 14.4 & 0 & -1.159 \\
17.0 & 1 & -1.661 \\
18.5 & 2 & -2.133 \\
19.4 & 3 & -2.582 \\
20.1 & 4 & -3.164 \\
\hline
\end{tabular}

Using the $\mathrm{L}_{t}$ values and their corresponding t' values (Table I) we obtained the following expression:

$$
\ln \left\{\left(L_{\infty}-L_{t}\right) / L_{\infty}\right\}=-1.15-0.493 t^{\prime}
$$

From (4) and (5) we have:

$$
-K t_{1}=1.15 \text { and }-K=-0.493
$$

Therefore $K=0.493$ and $\mathrm{t}_{1}=2.33$ (it must be an integer because the reproductive cycle in this population is a periodic annual one (SANTOS 1972). 


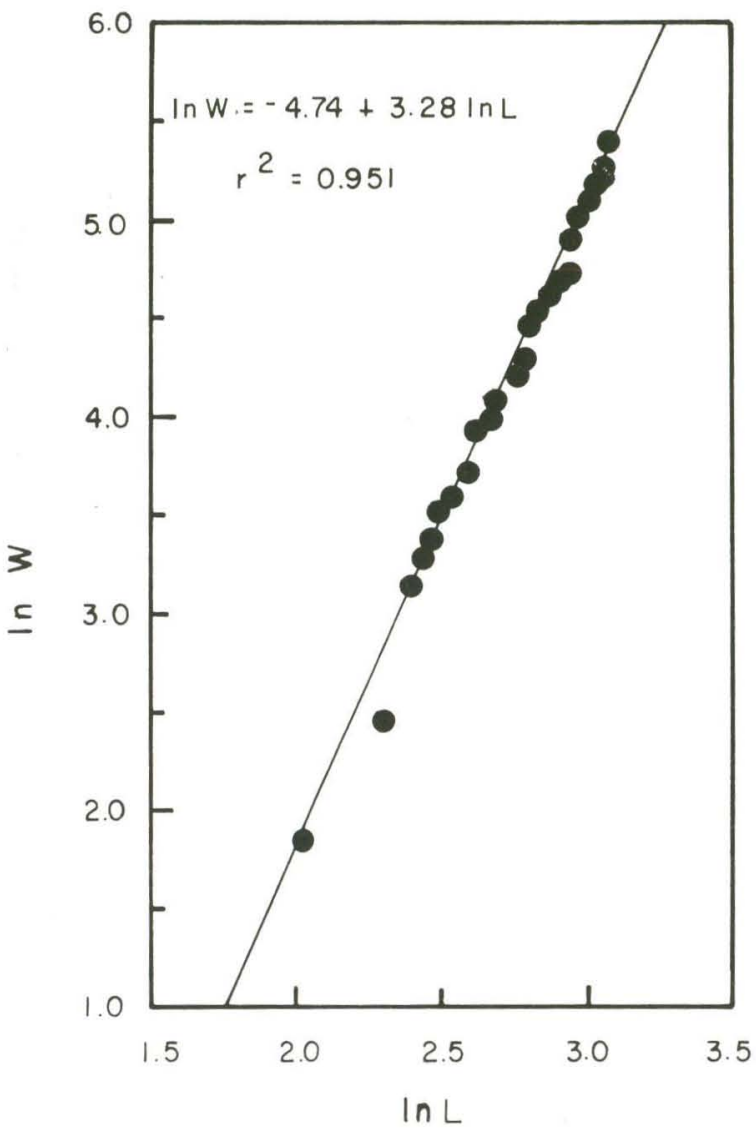

Fig. 2. Relationship between natural logarithms of the length (L) and weight (W) in $M$. carcinus females.

Figures 5 and 6 show, respectively, the length and weight growth curves of $M$. carcinus female with their equations.

\section{DISCUSSION}

The estimated mean maximum length for females of $M$. carcinus from Ribeira de Iguape river was $21.0 \mathrm{~cm}$. The length of those females becomes close enough to that asymptotic value from six years old on (Fig. 5).

The length growth curve estimated in our work is in agreement with data obtained by LEWIS et al. (1966) both in natural populations and in culture, which indicates that in this species, growth from 2.0 to $11.0 \mathrm{~cm}$ needs a period of 14 months.

The estimated mean maximum weight for females of $M$. carcinus was $190 \mathrm{~g}$. From eight years old on, females' weight becomes close enough to this value 


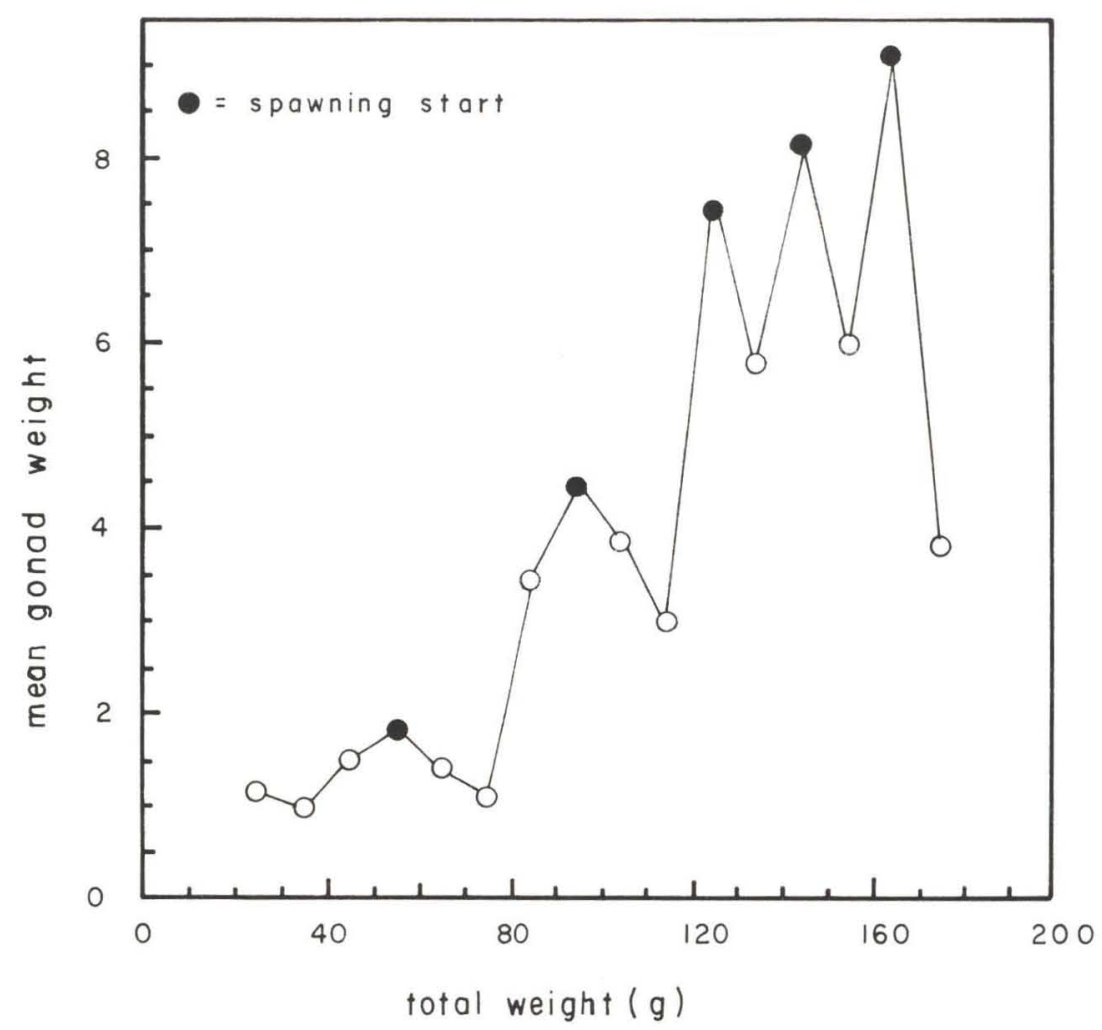

Fig. 3. Maturation curve obtained for $M$. carcinus females.

(Fig.6). It may be observed in figures 5 and 6, that the increase in weight is small, from the age when the individuals practically attain the mean maximum length.

Figures 3 and 6 suggest that M. carcinus reproductive life go on, at least animals attain six years old.

Comparison of $M$. carcinus growth curves with that of other species belonging to the same genus, is very difficult, firstly due to the small number of quantitative nature articles available in the literature and secondly due the heterogeneity of methods applied. Nevertheless, we could observe that $M$. carcinus effective growth period is longer than that for small species like M. amazonicum (Heller, 1862) (GUEST 1979), M. potiuna (Müller, 1880), M. borellii (Nobili, 1896) (BOND \& BUCKUP 1983) and M. acanthurus (VALENTI et al. 1987).

$M$. carcinus presents an $L_{\infty}$ value similar to or even higher than that of tropical species of great commercial interest, like Penaeus schmitti Burken, 1936 (NeIVA et al. 1971), Penaeus brasiliensis Latreille, 1817 and Penaeus paulensis Pérez Farfante, 1967 (Mello 1973). However, its growth rate is much smaller than that of the mentioned species, being comparable to that of some lobsters, which last several years to come close to the maximum length, as for example 


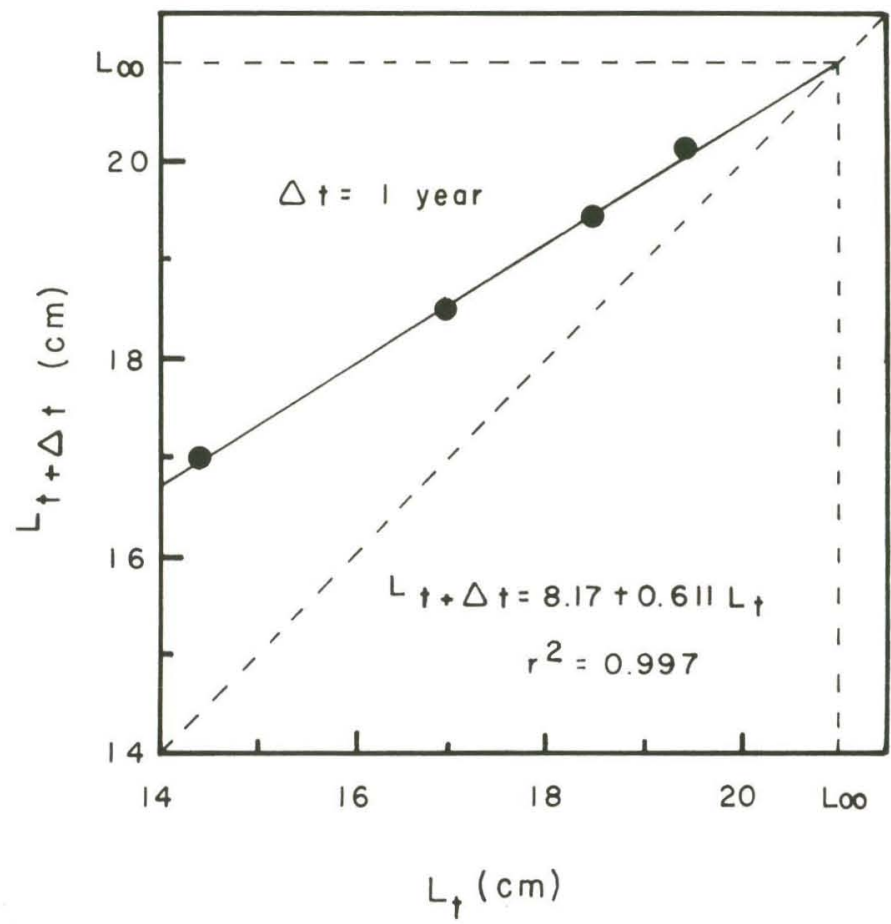

Fig. 4. Relationship between the mean length at one spawning $\left(L_{t}+\Delta_{t}\right)$ and the mean length at the preceding spawning $\left(\mathrm{L}_{1}\right)$ obtained for $M$. carcinus females (Ford-Walford transformation).

Panulirus argus (Latreille, 1804) (SANTos et al. 1964; Ivo 1975) and $P$. laevicauda (SANTOS \& IVO 1973).

The estimation of age and growth in crustaceans, is hampered by the absence of hard structures with periodic marks, due to the lost of the tegument in succeeding molts which also makes impossibly the application of marking methods (RAJYALAKSHMI 1966; HaRTNOLL 1982). Moreover, many species migrate seasonally and present a stratified distribution in relation to age, which makes difficulty the utilization of length frequency distribution methods (RAJYALAKSHMI 1966; MAUCHLINE 1977). So, the application of the maturation curve method to obtain the growth curve, presented in this work, may be of great interest in population studies of those animals.

Finally, we must point out that we could only obtain the growth curves for females as a result of the methodology applied in this work. However, we observed in the various analyzed samples that males and females presented similar lengths, being not characterized any evident sexual dimorphism in relation to body length, as it usually occurs in other species of Macrobrachium genus. 


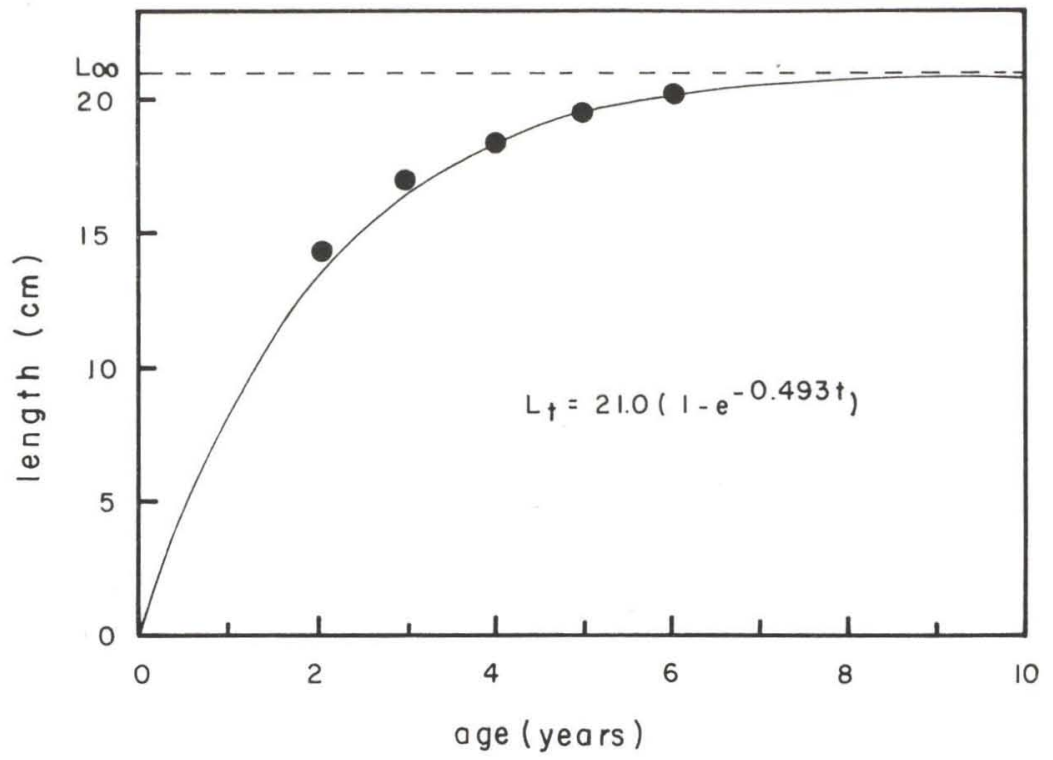

Fig. 5. Length growth curve fitted for $M$. carcinus females.

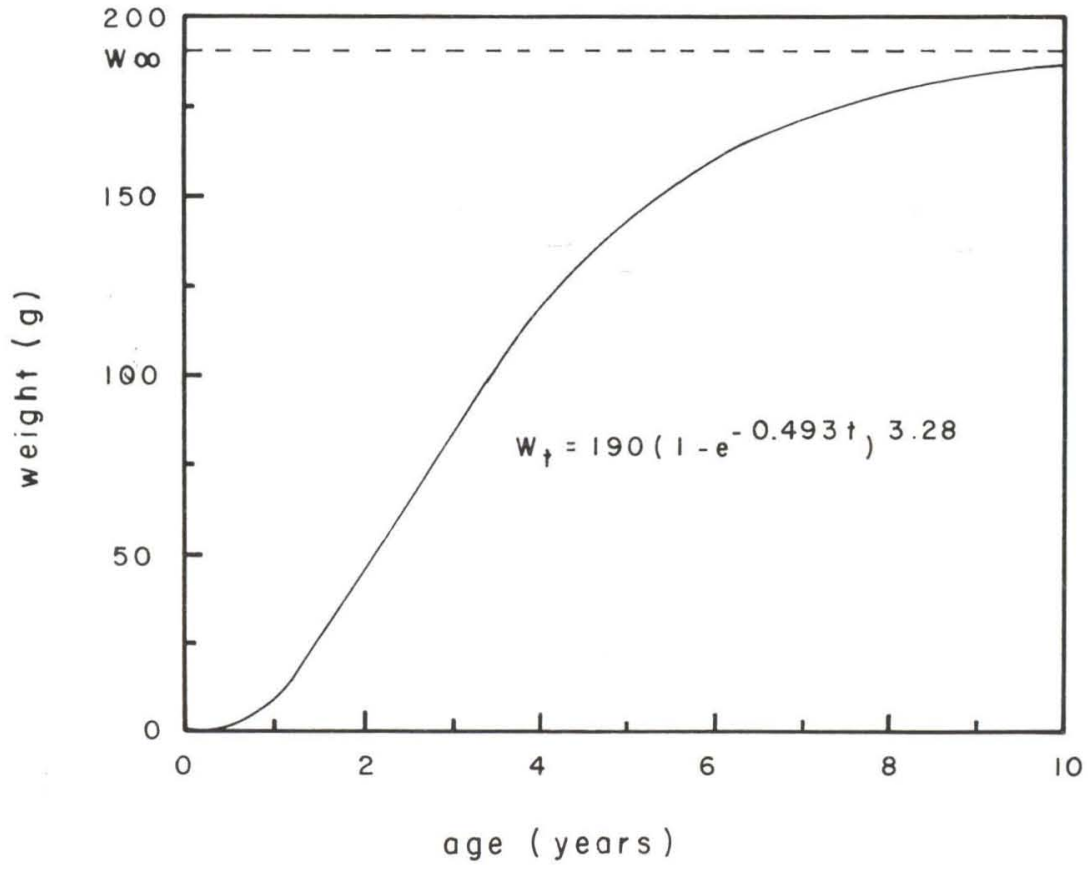

Fig. 6. Weight growth curve obtained for $M$. carcinus females. 
ACKNOWLEDGMENTS. We are grateful to Conselho Nacional de Desenvolvimento Científico e Teenológico (CNPq) for tinancial support and to Instituto de Pesca da Secretaria da Agricultura e Abastecimento de São Paulo for the facilities in the Registro city laboratory. We either like to thank Miss Maria de Fátina F. de Magalhães, a Cultura Inglesa English teacher, for the language revision.

\section{BIBLIOGRAPHIC REFERENCES}

Bagenal, T.B. 1978. Methods for assessment of fish production in fresh water. 3rd ed., I.B.P. Handbook, 3. Oxford, Blackwell Scientific, 365p.

BertalanfFy, L. Von. 1938. A quantitative theory of organic growth. Hum. Biol. 10: 181-213.

Beverton, R.J.H. \& S.J. Holt. 1957. On the dynamics of exploited fish population. Fishery Invest., London, ser. 2, 19: 1-533.

BOND, G. \& L. BUCKuP. 1983. O cultivo de Macrobrachium borelli (Nobili, 1896) e de Macrobrachium potiuna (Mułler, 1880) em laboratório. (Crustacea, Decapoda, Palaemonidae). Rev. Brasil. Biol. 43 (2): 177-190. . 1989. Os Palaemonidae de águas continentais do Brasil meridional. Rev. Brasil. Biol. 49 (4): 883-896.

Chauvin, W.D. 1992. Freshwater prawns in the USA - a market in transition. Infofish International 4: 17-19.

GuEST, W.C. 1979. Laboratory life history of the palaemonid shrimp Macrobrachium amazonicum (Heller) (Decapoda, Palaemonidae). Crustaceana 37 (2): 141-152.

Hartnoll, R.G. 1982. Growth, p.111-196. In: D.E. Bliss (Ed.) The Biology of Crustacea. Embryology, Morphology and Genetics. New York, Academic Press, v.2, 383p.

Holthuls, L.B. 1952. A general revision of the Palaemonidae (Crustacea, Decapoda, Natantia) of the Americas. II. The sub-family Palaemoninae. Occ. Pap. Allan Hancock Fdn. 12: 1-396.

1980. FAO species catalogue. Vol. 1. Shrimps and prawns of the world. An annotated catalogue of species of interest to fisheries. FAO Fish Synopses, Rome, 1 (125): $261 \mathrm{p}$.

Ivo, C.T.C. 1975. Novo estudo sobre o crescimento e idade da lagosta Panulirus laevicauda (Latreille) em águas costeiras do Estado de Ceará (Brasil). Arq. Ciênc. Mar. 15 (1): 29-32.

LEWIS, J.B., WARD \& A. MCIVER. 1966. The breeding cycle, growth and food of fresh water shrimp Macrobrachium carcinus (Linnaeus) Crustaceana 10 (1): 48-52.

Ling, S.W. \& T.J. Costello. 1976. Review of culture of fresh water prawns. FAO Tech. Conf. Aquacult., FIR; AQ/Conf. 176/ R -29p.

Mauchline, J. 1977. Growth of shrimps, crabs and lobsters: an assessment. J. Cons. Int. Explor. Mer. 37 (2): 162-169.

Mello, J.T.C. DE. 1973. Estudo populacional do Camarão Rosa, Penaeus 
brasiliensis (Latreille, 1817) e Penaeus paulensis (Perez - Farfante, 1967). B. Inst. Pesca 2 (2): 19-65.

Neiva, G.S.; E.P. Santos \& V. JanKauskis. 1971. Análise preliminar da população de camarão legítimo Pancteus schmitti, Bukenroad, 1936, na Baía de Santos - Brasil. B. Inst. Pesca 1 (2): 7-14.

Pauly, D. 1980. A Selection of simple methods for the assessment of tropical fish stocks. FAO Fish. Circ., Rome (729), 54p.

Rabanal, H.R. 1982. The fishery for palaemonid species and the need and potential for their culture, p.309-331. In: M.B. NEW (Ed.) Giant prawn farming, Amsterdam, Elsevier, 532p.

Rajyalakshmi, T. 1966. On the age and growth of some estuarine prawns. Proc. Indo-Pacif. Fish. Coun. 11 (II): 52-83.

Santos, E.P. 1972. Sobre a análise da curva de maturação. B. Inst. Pesca 1 (7): $55-62$.

1978. Dinâmica de populações aplicada à pesca e piscicultura. São Paulo. HUCITEC/EDUSP, 130p.

Santos, E.P.; R.S. DA COSTA \& S.J.C. DE Moura. 1964. Growth of spine lobster Panulirus argus (Latr.): quantitative aspect. Arq. Est. Biol. Mar. Univ. Ceará 4 (2): 41-44.

Santos, E.P. \& C.T.C. Ivo. 1973. Crescimento e idade da lagosta Pamulirus laevicauda (Latreille), em águas costeriras do Estado do Ceará (Brasil). Arq. Ciênc. Mar. 13 (1): 19-23.

VAlENTI, W.C.; J.T.C. Melo \& V.L. LoBÃO. 1986. Dinâmica da Reprodução de Macrobrachium acanthurs (Wiegmann, 1836) e Macrobrachium carcinus (Linnaeus, 1758) do Rio Ribeira de Iguape (Crustacea, Decapoda, Palaemonidae). Cienc. Cult. 38 (7): 1256-1262.

1977. Crescimento de Macrobrachium acanthurus (Wiegmann, 1836) do Rio Ribeira de Iguape (Crustacea, Decapoda, Palaemonidae). Rev. Brasil. Biol. 47 (3): 349-355.

WALFORD, L.A. 1946. A new graphic method of describing the growth of animals. Biol. Bull. mar. biol. lab. 90 (2): 141-147.

Weatherley, A.H. 1972. Growth and Ecology of Fish Populations. London, Academic Press, 293p.

Recebido em 30.III.1994; aceito em 11.X.1994 